\title{
Assessment of Water Quality and Eutrophication Status of UlsoorLake, Bangalore, Karnataka, India
}

\author{
Vyshnavi D R ${ }^{1}$ and Shivanna $S^{2}$
}

\author{
${ }^{1}$ Assistant Professor, Dept. of Civil Engineering, \\ Sir M. Visvesvaraya Institute of Technology, International Airport Road, \\ Bangalore 562-157, India \\ ${ }^{2}$ Associate Professor, Dept. of Civil Engineering, \\ Sir M. Visvesvaraya Institute of Technology, International Airport Road, \\ Bangalore 562-157, India
}

\begin{abstract}
Ulsoor Lake is situated at a location surrounded by large number of residential dwellings and commercial areas. The lake water is not used as a source for water supply but the demand to do so is easily foreseen. In the present study water samples were collected at the sewage inlets before the bund as well as across the length of the lake to check the quality and eutrophication status. The region near the sewage inlets is found to be hyper eutrophic in nature with substantial amount of algal bloom and other solid wastes While the water of the lake is found to be mesotrophic in nature.
\end{abstract}

Key words: Eutrophication status, Trophic status index, Physico-chemical parameters.

\section{Introduction}

Water is the most common liquid on our planet, vital to all life forms. It is the dispersion medium for all biochemical reactions of the living process and takes part in many of these reactions. In spite of the chemical simplicity of the water molecule, its physical properties are quite remarkable. Water is the most essential requisites that nature has provided to sustain life on earth. Sources of water can be broadly classified as; in to: Surface water bodies such as oceans, rivers, ponds and lakes, streams; sub-surface water bodies such as ground water and soil moisture and atmospheric water. Lake is an inland surface water body and it can be defined as natural large depression formed within the surface of the earth that is filled with water. Lakes are a habitat for an immense variety of plants and animals. These plants and animals are linked together in a complicated system of interdependence and if one part is disturbed, the whole system is upset. This system works as follows: the plants use sunlight, nutrients absorbed from the ground and water, and gases (carbon dioxide and oxygen), to grow. The animals eat the plants, which may then be eaten by other animals, then bacteria decomposes the dead plants and animals back into simpler compounds that can then be used as nutrients by living things such as plants. This constitutes the food web of a lake. All these processes -require oxygen in order to take place (Mishra and Yadav 1978). Decomposition is vital to the lakes because without it the lakes would fill up with dead plant and animal material. A lake represents lentic (standing water) ecosystems and they vary considerably in physical, chemical and biological characteristics. All these characteristics depends on many factors like how it was formed, size and shape of the lake basin, topography, regional climate, local biological communities and various human activities. The rapid pace of industrialization, agriculture development and increase in human population, has posed a serious threat to water quality of lakes and impoundments. The lake becomes nutrient rich; this promotes growth of algae and other aquatic plants, increasing the productivity of lakes and thereby leading to eutrophication. Due to this the earth surface is rapidly losing natural water bodies and it is of grave concern to our environment. A lake's productivity level may be determined by measuring the amount of algal growth that is supported by available nutrients. This productivity level of a lake is thus, a reflective of the water quality of the lake. As the productivity of a lake increases the water quality reduces, thus productivity forms a basis for classifying lakes (Lodh et al. 2014, Mishra et al 2014). 


\section{Salient Features of the Lake}

Ulsoor lake, one of the biggest lakes in Bangalore and is located on the eastern side of the city (Seema et al. 2018). It derives its name from the name of the locality it is situated namely, Ulsoor is spread over 50 ha and has several islands (Randhwa et al. 2010, Patil 2011, Sinha et al. 2013, Anima Upadahyay and Chandrakala 2015, Meenu et al. 2015, Rao 2015, Khanna 2016). Even though the lake is dated to Kempegowda's time, the present lake was created by Sir Lewin Bentham Bowring, the then Commissioner of Bangalore.

\section{Sample Collection}

Care was to be taken to ensure that the sampling bottles were treated with $10 \%$ dilute $\mathrm{HCl}$ and subsequently washed with distilled water. The samples were analysed immediately for odour, colour $\mathrm{pH}$ and rest of the samples was refrigerated at $4^{\circ} \mathrm{C}$ to be analysed later. Sample analysis was done as per standard procedures mentioned in APHA and AWWA, 2005. Temperature, transparency, turbidity, $\mathrm{pH}$, dissolved oxygen (DO), biological oxygen demand (BOD), chemical oxygen demand (COD), nitrate $(\mathrm{N})$, phosphates $(\mathrm{P})$ and chlorophyll-A were determined in the laboratory.

\section{Sample Location}

In the present study five samples of the lake were collected at various to study the various parameters of water (Table 1$)$.

Table 1: Details of Sampling Location

\begin{tabular}{|c|c|c|c|}
\hline \multirow{2}{*}{ Sampling Locations } & \multirow{2}{*}{ Points } & \multicolumn{2}{|c|}{ GPS Readings } \\
\cline { 3 - 4 } & & latitude & longitude \\
\hline Station 1 & A & $12.985924^{\circ} \mathrm{N}$ & $77.620380^{\circ} \mathrm{E}$ \\
\hline Station 2 & B & $12.986629^{\circ} \mathrm{N}$ & $77.621626^{\circ} \mathrm{E}$ \\
\hline Station 3 & C & $12.985924^{\circ} \mathrm{N}$ & $77.620380^{\circ} \mathrm{E}$ \\
\hline Station 4 & D & $12.983872^{\circ} \mathrm{N}$ & $77.621614^{\circ} \mathrm{E}$ \\
\hline Station 5 & E & $12.980156^{\circ} \mathrm{N}$ & $77.620740^{\circ} \mathrm{E}$ \\
\hline
\end{tabular}

\section{Trophic State Index (TSI)}

In the present study, the Carlson Trophic State Index (TSI) was used to provide a single quantitative index for the purpose of classifying and ranking lakes and to assess the trophic state of the lake. In recent years the Carlson index appears to have attained general acceptance in the limnological community as a reasonable approach to this problem. This is a measure of the trophic status of a body of water using several measures of water quality including transparency or turbidity using Secchi disk depth (SD) recordings, chlorophyll-A (CHLA) concentrations (algal biomass) and total phosphorus (TP).

There has been a tendency to average the three variables rather than to prioritize their use. Perhaps this is just a natural tendency for humans to seek the central tendency, or it might reflect the concept that the trophic state is defined by a number of variables:

Average TSI $=[$ TSI $(\mathrm{TP})+\mathrm{TSI}(\mathrm{CHLA})+\mathrm{TSI}(\mathrm{SD}) / 3]$

Table 2: Classification Scheme of the Trophic State Index

\begin{tabular}{|c|c|c|c|c|c|}
\hline TSI & $\begin{array}{l}\text { Chl-a } \\
(\mu g / L)\end{array}$ & $\mathrm{SD}(\mathrm{cm})$ & $\begin{array}{c}\text { TP } \\
(\mu g / L)\end{array}$ & Attributes & $\begin{array}{l}\text { Fisheries \& } \\
\text { Recreation }\end{array}$ \\
\hline$<30$ & $<0.95$ & $>26.2$ & $<6$ & $\begin{array}{l}\text { Oligotrophy: Clear } \\
\text { water, oxygen } \\
\text { throughout the year at } \\
\text { the bottom of the } \\
\text { lake, very deep cold } \\
\text { water. }\end{array}$ & $\begin{array}{l}\text { Trout fisheries } \\
\text { dominate }\end{array}$ \\
\hline $30-40$ & $0.95-2.6$ & $13.1-26.2$ & $6-12$ & $\begin{array}{l}\text { Bottom of shallower } \\
\text { lakes may become } \\
\text { anoxic (no oxygen). }\end{array}$ & $\begin{array}{l}\text { Trout fisheries in } \\
\text { deep lakes only. } \\
\text { Walleye, Tullibee } \\
\text { present. }\end{array}$ \\
\hline $40-50$ & $2.6-7.3$ & $6.6-13.1$ & $12-24$ & $\begin{array}{l}\text { Mesotrophy: Water } \\
\text { moderately clear } \\
\text { most of the summer. } \\
\text { May be "greener" in } \\
\text { late summer. }\end{array}$ & $\begin{array}{l}\text { No oxygen at the } \\
\text { bottom of the lake } \\
\text { results in loss of } \\
\text { trout. Walleye may } \\
\text { predominate. }\end{array}$ \\
\hline $50-60$ & $7.3-20$ & $3.3-6.6$ & $24-48$ & $\begin{array}{l}\text { Eutrophy: Algae and } \\
\text { aquatic plant } \\
\text { problems possible. } \\
\text { "Green" water most } \\
\text { of the year. }\end{array}$ & $\begin{array}{l}\text { Warm-water fisheries } \\
\text { only. Bass may } \\
\text { dominate. }\end{array}$ \\
\hline $60-70$ & $20-56$ & $1.6-3.3$ & $48-96$ & $\begin{array}{l}\text { Blue-green algae } \\
\text { dominate, algal } \\
\text { scums and aquatic } \\
\text { plant problems. }\end{array}$ & $\begin{array}{l}\text { Dense algae and } \\
\text { aquatic plants. Low } \\
\text { water clarity may } \\
\text { discourage } \\
\text { swimming and } \\
\text { boating. }\end{array}$ \\
\hline $70-80$ & $56-155$ & $0.8-1.6$ & $96-192$ & $\begin{array}{l}\text { Hypereutrophy: (light } \\
\text { limited productivity). } \\
\text { Dense algae and } \\
\text { macrophytes. }\end{array}$ & $\begin{array}{l}\text { Water is not suitable } \\
\text { for recreation. }\end{array}$ \\
\hline$>80$ & $>155$ & $<0.8$ & $192-384$ & $\begin{array}{l}\text { Algal scums, few } \\
\text { aquatic plants }\end{array}$ & $\begin{array}{l}\text { Rough fish (carp) } \\
\text { dominate; summer } \\
\text { fish kills possible }\end{array}$ \\
\hline
\end{tabular}

\section{Results and Discussion}

During the study period (in the month of May), the following physical and chemical and biological parameters were analysed viz., temperature, transparency, $\mathrm{pH}$, nitrate, phosphate, electrical conductivity, dissolved oxygen, BOD, COD, Total Coliform and chlorophyll-A. The results obtained are shown in different tables. 


\subsection{Temperature}

Temperature variations in Ulsoor lake at stations A, $\mathrm{B}, \mathrm{C}, \mathrm{D}$ and $\mathrm{E}$ on weekly basis is shown in Figure 1. The excessive amount of nutrients in the water bodies along the higher temperature favours the growth of algae and aquatic weeds. Temperature is directly affected by physical and biological characteristics of waterways.

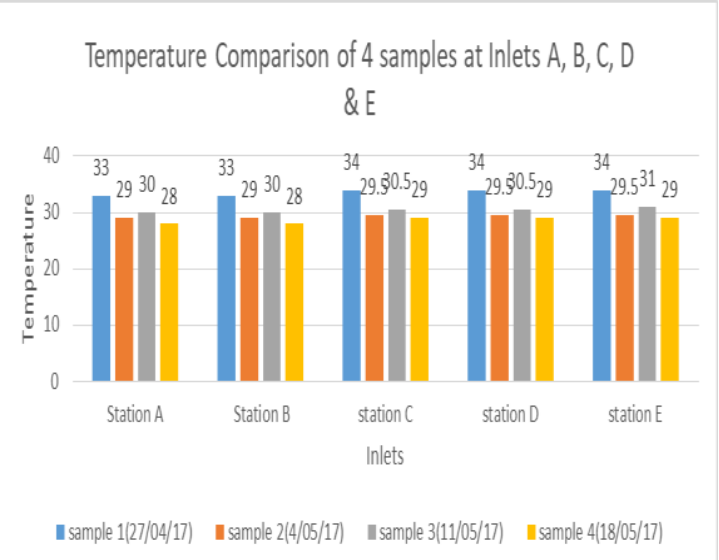

Fig.1: Temperature variation at different station on weekly basis.

\subsection{Turbidity}

The Variation of turbidity in Ulsoor lake at different station A, B, C, D and E is shown in the above Fig 2. The turbidity levels are uncertain from station A to E.

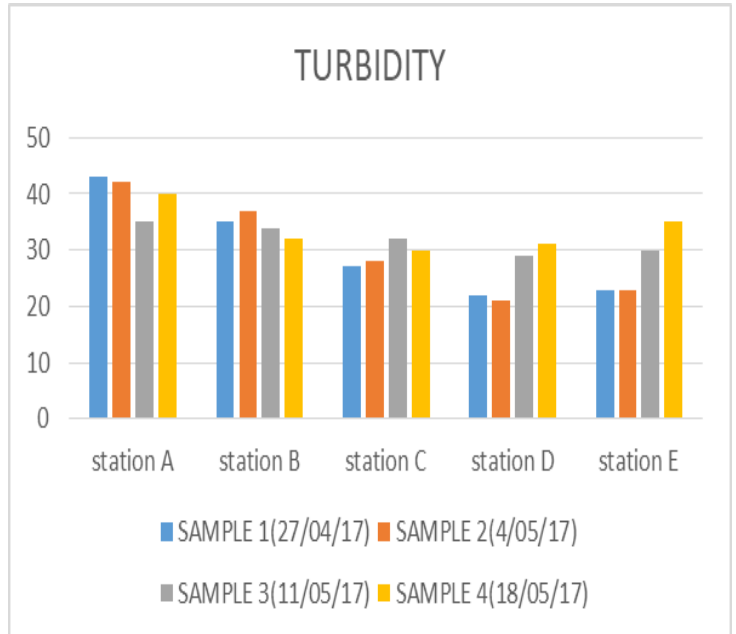

Fig. 2: Variation of turbidity at different station on weekly basis.

\subsection{Transparency}

The variations in transparency at different stations A, $\mathrm{B}, \mathrm{C}, \mathrm{D}$ and $\mathrm{E}$ is shown in figure 3. Transparency determines the photic conditions of the lake. The higher value of transparency very clearly speaks the low values of turbidity of lake water especially during summer period.
ISSN 2455-6378

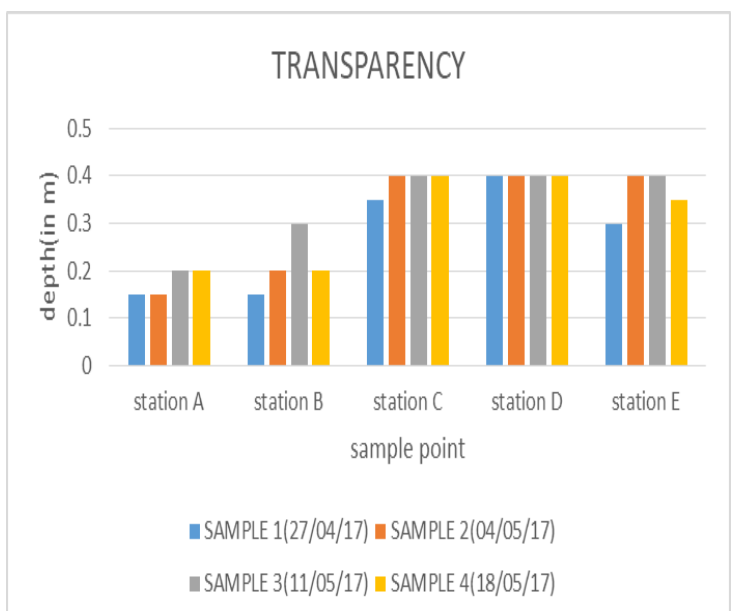

Fig. 3: Variation of Transparency at different station on weekly basis.

In station 1 and 2 the transparency of water is less due to the entry of raw sewage at that inlet point. Transparency indicates the extent of turbidity and also measures the light penetration through the water. Reduced transparency during summer is due to increase of suspended particles on account of organic debris' decomposition with higher water temperature and reduced flow.

\section{$6.4 \mathrm{pH}$}

Variation of pH in Ulsoor lake is shown (Fig 4) The $\mathrm{pH}$ indicates the acidity or alkalinity of water. $\mathrm{pH}$ is an important parameter because it controls the state of various nutrients including nitrate, phosphate, DO etc. The permissible limit for both drinking water and irrigation is 6.5 to 8.5 . In the present study the $\mathrm{pH}$ values are increasing (Fig.4) and it may be due to release of municipal sewerage.

\subsection{Phosphate}

Variation of Phosphate in Ulsoor lake is shown in Fig 5. In an aquatic ecosystem inorganic phosphate as soluble orthophosphate plays a dynamic role In eutrophic lakes high phosphate content supports an increased level of primary production till nitrogen become limiting. The increasing trend of eutrophication as observed in present investigation may adversely affect the recreational value of the lake. 


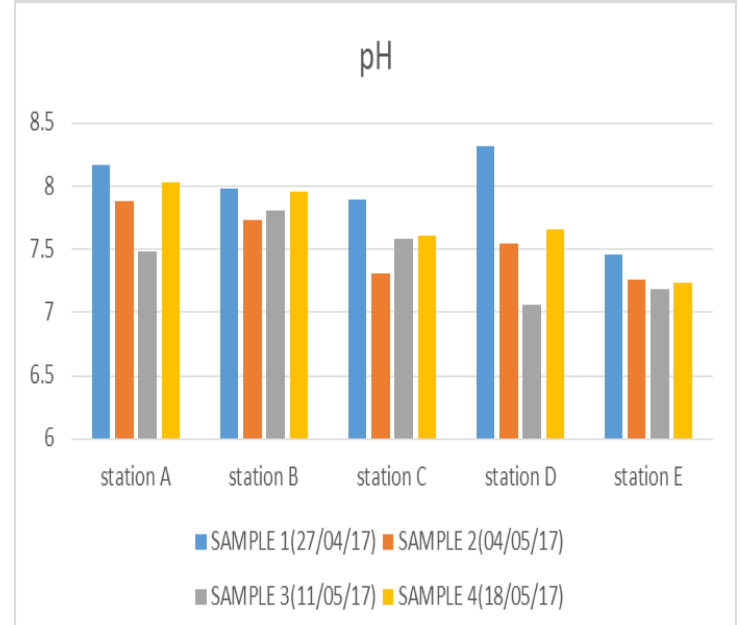

Fig.4: Variation of $\mathrm{pH}$ at different station on weekly basis.

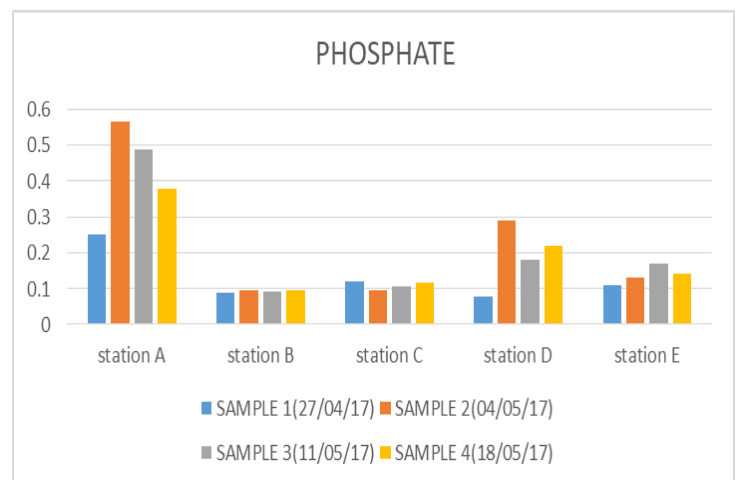

Fig. 5: Variation of Phosphate at different station on weekly basis.

The permissible limit of phosphate is $0.050 \mathrm{mg} / \mathrm{L}$. The phosphate content of the water was in the range of 0.076 to $0.567 \mathrm{mg} / \mathrm{L}$. The United States Public Health Standards limit for phosphates in drinking water is $0.1 \mathrm{mg} / \mathrm{L}$.

\subsection{Electrical Conductivity}

Variation of electrical conductivity is shown in the Figure 6. At the inlet, EC values are high due to the presence of more dissolved solids and the values decrease due to dilution taking place in the lake. Conductivity itself is not a human or aquatic health concern, but because it is easily measured, it can serve as an indicator of other water quality problems (It is used to give an indication of the amount of inorganic materials in the water).

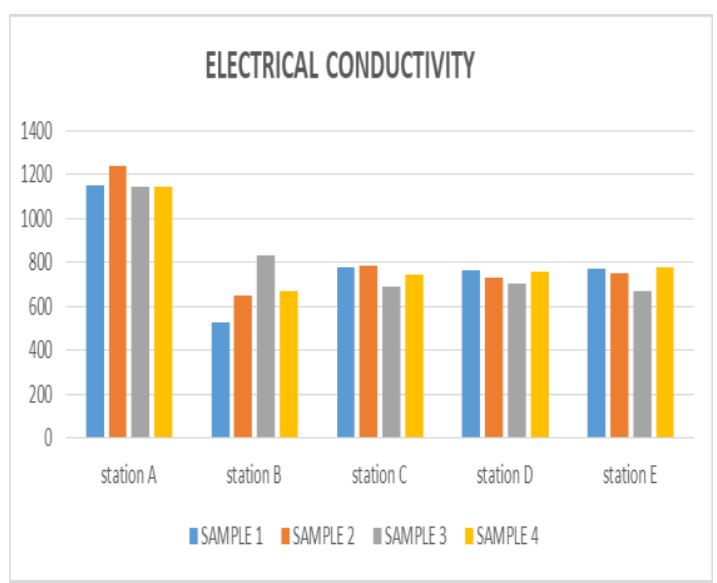

Fig. 6: Variation of Electrical conductivity at different station on weekly basis.

\subsection{Total Dissolved Solids}

Variation of Total Dissolved Solids at the 5 stations is shown in Fig 7. Except in station E the TDS is almost uniform in all other stations.

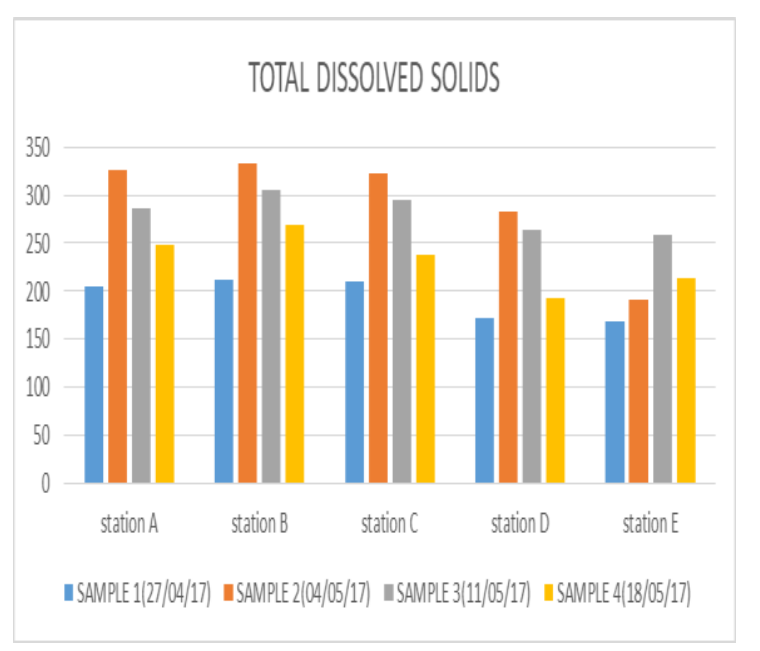

Fig.7: Variation of Total Dissolved Solids at different station on weekly basis.

\subsection{Dissolved Oxygen}

The dissolved oxygen (DO) is very important in an aquatic eco-system. It is considered as the pollution indicator parameter. It reflects the biological activity taking place in a water body and also determines the biological changes, which is due to aerobic and anaerobic organisms (Figure 8). The lower concentration of DO explains its quick utilization in the oxidation processes of the lake. Low DO at inlet indicates hypoxic conditions. 


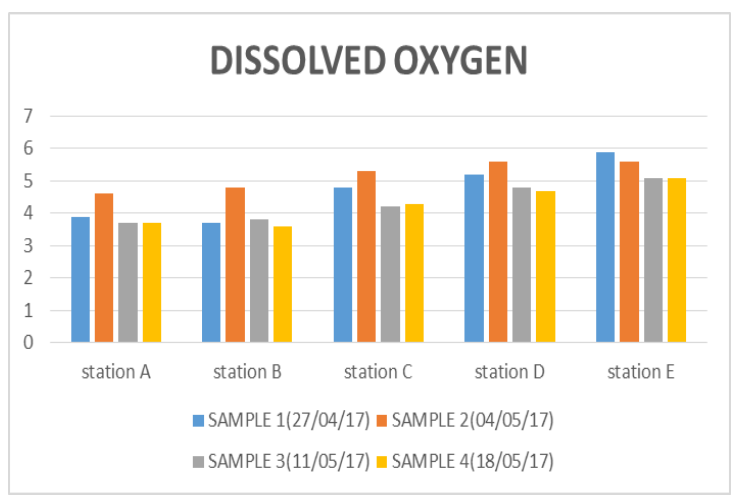

Fig. 8: Variation of DO at different station on weekly basis.

Hypoxic and anoxic conditions can be correlated with a higher demand for oxygen for bacterial decomposition and consequently, creates an anaerobic environment.

\subsection{Biochemical Oxygen Demand}

Biochemical Oxygen Demand (BOD) is the amount of dissolved oxygen required for stabilizing the biodegradable organic matter by microorganisms in the sample under aerobic conditions in a stated time. It is a good index of the organic pollution and helps in deciding suitability of water for human consumption.

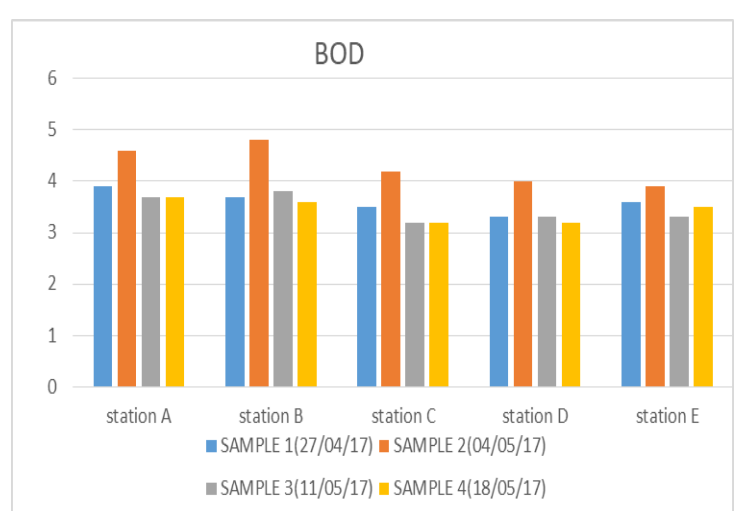

Fig. 9: Variation of BOD at different station on weekly basis.

The permissible BOD limit is $3 \mathbf{~ m g} / \mathbf{l}$. BOD values ranged from 3 to $5 \mathrm{mg} / \mathrm{l}$.

\subsection{Chemical Oxygen Demand}

Chemical Oxygen Demand (COD) is an important parameter for knowing the quality of water. It is a measure of the oxygen requirement of a sample that is susceptible to oxidation by a strong chemical oxidant. The COD test is more rapid and more reliable than the BOD test. Chemical oxygen demand (COD) does not differentiate between biologically available and inert organic matter and it is a measure of the total quantity of oxygen required to oxidize all organic material into carbon dioxide and water.

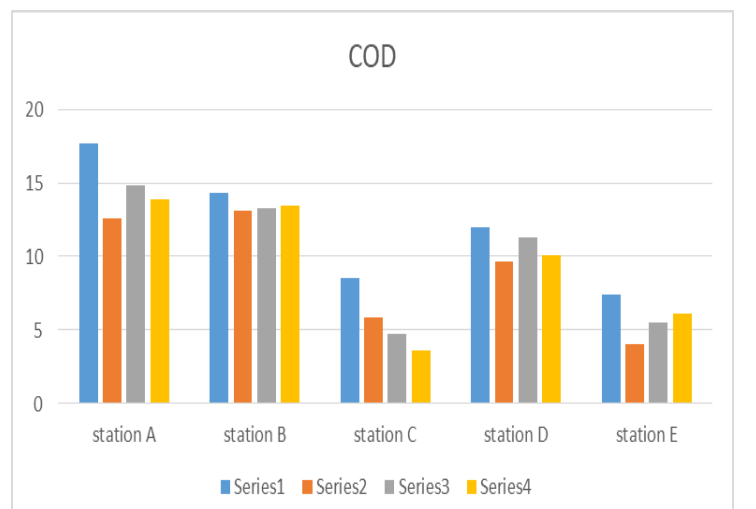

Fig. 10: Variation of COD at different station on weekly basis

Again, the values reported are too low to be realistic in sewage water.

\subsection{Chlorophyll A (Chla)}

To find out the amount chlorophyll $\mathrm{A}$ in the Ulsoor lake water test has been conducted and the value of chlorophyll-A is $0.0076 \mathrm{mg} / \mathrm{l}$ (Table 3). Biological tests were also conducted to confirm the presence of E.coli (Table 4)

Table 3: Showing the value of chlorophyll-A

\begin{tabular}{|c|l|}
\hline $\begin{array}{l}\text { Spectrometric wavelength } \\
\text { (in } \mathrm{nm})\end{array}$ & Absorption \\
\hline $\mathbf{6 4 5}$ & $\mathbf{0 . 0 2 1}$ \\
\hline $\mathbf{6 6 3}$ & $\mathbf{0 . 0 6 5}$ \\
\hline $\mathbf{6 5 2}$ & $\mathbf{0 . 0 3 9}$ \\
\hline
\end{tabular}

Table 4: Showing the results for Biological test

\begin{tabular}{|l|l|}
\hline Presumptive Test & $\begin{array}{l}\text { +ve result Indicating } \\
\text { high bacterial content. }\end{array}$ \\
\hline Confirm Test & $\begin{array}{l}\text { +ve result Indicating } \\
\text { presence of Coliform } \\
\text { bacteria. }\end{array}$ \\
\hline Completed Test & $\begin{array}{l}\text { +ve Result for E-coli } \\
\text { bacteria. }\end{array}$ \\
\hline
\end{tabular}

\section{Conclusions}

Based on average TSI calculation, water near sewer inlet is in hypereutrophic condition whereas the water after the bund is mesotrophic in nature. The temperature of the sewage is found to be normal and at par with lake water sample, whereas the transparency of the water in cordoned part is very 
less as compared to lake water due to factors like algal growth and colour of waste water entering thus resulting in high turbidity in area near inlets. The $\mathrm{pH}$ of the wastewater and the lake water are found within the desired limit (within 6.5-8.5). Based on DO at sewage inlet, it is stressful condition for aquatic life to survive, but DO measured at main lake water is favourable and support spawning of aquatic life. BOD content at is within the desirable limit at the sewer inlet and main water body i.e., $<5 \mathrm{mg} / \mathrm{l}$, but required treatment if used for any domestic purposes. COD is found well within the permissible limit. TDS is found below the standard limits (i.e. 500 $\mathrm{mg} / \mathrm{l})$. The electrical conductivity is found to be above the ICMR standard due to presence of dissolved in both lake water as well as sewage water.

Presence of chlorophyll a (CHLA) pigment in sewage sample results in significant amount of algal growth, whereas the amount of CHLA in lake water is comparatively insignificant. Accumulation and stagnation of waste water could lead to genesis of several diseases, accelerated by the presence of significant amount of E.coli. Based on these aspects it is concluded that the Ulsoor lake water is not suitable for direct human consumption as well as for any other domestic utilisation.

\section{References}

[1] Anima Upadhyay and M Chandrakala (2015): Pre- and Post-monsoon Study of Physico-Chemical Parameters of Ulsoor Lake Water of Bangalore, Karnataka, India, International Journal of Innovative Research in Science, Engineering and Technology., Vol.4, Issue 5, pp 2828-2832.

[2] Bosky Khanna (2016): Sewage, excess fish polluted Ulsor Lake, Decan Herald, March 20,

[3] Chandan Kumar Sinha, Sudip Mandal, Sarit Pritam Dwibedy and Santanu Dey (2013): Study on Water Quality by Physico-chemical and Bacteriological Method of various Lakes of Bangalore, Karnataka., Indian Journal of Research., Vol.2., Issue 12., pp.13-15.
[4] R Lodh, R Paul, B Karmakar and M K Das (2014): Physico-chemical Studies of Water Quality with Special reference to Ancient Lakes of Udaipur city, India., International Journal of Scientific and Research publication., Vol.4., No.8(6).

[5] Meher Randhawa, Praveen Dharmal and Antony (2010): The role of the army in the rejuvenation of Ulsoor lake., Wetlands, Biodiversity and Climate.

[6] S Meenu, T Pavanika, D Praveen, $\mathbf{R}$ Ushakiran, G Vinodkumar and Sheriff Vaseem Anjum (2015): Ulsoor Lake: Grey to Green, Indian Journal of Science and Technology, Vol.8(28), pp.16.

[7] G.P. Mishra and A.K. Yadav (1978): A Comparative Study of Physico-chemical Characteristics of River and Lake water in the Central India., Hydrobiologica., Vol.59., Issue 3., pp. 275-278.

[8] Mohit M Rao (2015): Results of the Tests on Ulsoor Lake is Alarming., The Hindhu., March.

[9] N. K Patil (2011): Preservation of Lakes in City of Bangalore - Report of the committee constituted by Hon'ble High Court of Karnataka to Prepare an Action plan for Preservation of Lakes.

[10] Sachin Mishra, Ashalatha Singh and Dharmesh Tiwary (2014): Studies of Physicochemical status of the forms at Varanasi Holy city under Anthropogenic influences. International Journal of Environmental Research and Development, Vol.4, No.3., pp.261-268.

[11] Seema Mundoli, Manjunath B. and Harini Nagendra (2018): Lakes of Bengaluru: The Once Living But now Endangered Peri-Urban Commons., Azim Premji University, Working paper 10., pp.121. 